\title{
Esthetic impact of gingival plastic surgery from the dentistry students' perspective
}

\author{
Erdem Ayyildiz ${ }^{1}$, Enes $\operatorname{Tan}^{1}$, Hakan Keklik ${ }^{1}$, Zulfikar Demirtag ${ }^{2}$, Ahmet Arif Celebi ${ }^{3}$, \\ Matheus Melo Pithon ${ }^{4}$
}

Correspondence: Dr. Hakan Keklik

Email: hakan_keklik42@hotmail.com

\author{
'Department of Orthodontics, Faculty of Dentistry, \\ Kirikkale University, Kirikkale, Turkiye, \\ 2Department of Prosthodontics, Faculty of Dentistry, \\ Kirikkale University, Kirikkale, Turkiye, \\ ${ }^{3}$ Department of Orthodontics, Faculty of Dentistry, \\ Zirve University, Gaziantep, Turkiye, \\ ${ }^{4}$ Department of Health, Southwest Bahia State \\ University-UESB, Jequie, Bahia, Brazil
}

\section{ABSTRACT}

Objective: The aim of the this study was to evaluate the perception of smile esthetics and alterations in cases of gingival plastic surgery for correction of a gummy smile, by means of alterations in smile photograph among dentistry degree students. Materials and Methods: A frontal smile photograph of a 40-year-old woman having normal occlusion was used with diverse compositions of gingival exposure level and crown length of maxillary teeth. The eight photographs were evaluated by 216 dentistry students in five class groups $\left(1^{\text {st }}, 2^{\text {nd }}, 3^{\text {rd }}, 4^{\text {th }}\right.$ and $5^{\text {th }}$ classes $)$. Results: The results revealed that almost all of the class' students perceived differences between images, additionally, the highest percentage of students that answered "no difference" was $12 \%$ at $1^{\text {st }}$ class' students. $1^{\text {st }}$ and $2^{\text {nd }}$ class' students most liked photograph which is $2.5 \mathrm{~mm}$ gingival display and $3^{\text {rd }}$ class students liked two different photographs which are $2.5 \mathrm{~mm}$ gingival display and $2 \mathrm{~mm}$ gingival display whereas $4^{\text {th }}$ class students preferred two different photographs which are $1.5 \mathrm{~mm}$ gingival display and $1 \mathrm{~mm}$ gingival display, $5^{\text {th }}$ class students preferred photograph which is $1.5 \mathrm{~mm}$ gingival display as the most. Conclusion: Esthetic perception of smile improve as a student passes to higher study classes in terms of gingival exposure. The harmonious display of gingiva exhibits an important effect in the smile esthetics rather than reduced or excessive display.

Key words: Clinical crown of maxillary anterior teeth, esthetics, perception, periodontal surgery, photography

\section{INTRODUCTION}

Facial beauty attached to some factors, personal opinion, cultural factors and media influence are a few of them. ${ }^{[1]}$ The harmonious smile has been considered as the indicator of facial attractiveness and beauty since the beginning of humanity. This smile effects social interaction, interpersonal success, person's self-confidence and also business performance. ${ }^{[2]}$

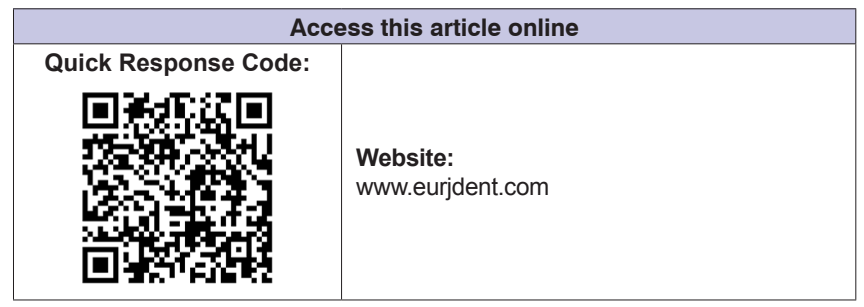

For these reasons, one of the most crucial goals of orthodontic therapy is analysis and design of the smile. ${ }^{[3]}$

The concept of ideal smile is related with the position, color and shape of anterior teeth and a good harmony between lip and gingiva.

This is an open access article distributed under the terms of the Creative Commons Attribution-NonCommercial-ShareAlike 3.0 License, which allows others to remix, tweak, and build upon the work non-commercially, as long as the author is credited and the new creations are licensed under the identical terms.

For reprints contact: reprints@medknow.com

How to cite this article: Ayyildiz E, Tan E, Keklik H, Demirtag Z, Celebi AA, Pithon MM. Esthetic impact of gingival plastic surgery from the dentistry students' perspective. Eur J Dent 2016;10:397-402.

DOI: $10.4103 / 1305-7456.184164$ 
The normal smile is characterized with 1-3 mm exposure of gingiva including interdental and marginal tissue. ${ }^{[4]}$ If the gingival display is more than $3 \mathrm{~mm}$, it is defined as gummy or gingival smile which is unesthetic. ${ }^{[5,6]}$

Depending on true diagnosis, excessive gingival display can be stemmed from vertical maxillary skeletal excess, short upper lip, gingival hypertrophy and short clinical crowns of anterior teeth. All these problems should be evaluated with interdisciplinary approach including orthodontic, periodontal and prosthetic treatments. ${ }^{[7]}$

When there is no skeletal vertical maxillary excess, the correction of gummy smile can be made with altering of the natural relationship between the clinical crowns and gingival tissue. If there is a gingival hypertrophy and/or short clinical crowns, gingival plastic surgery is performed.

There are many studies evaluating esthetic perception degree of laypersons, professionals, and dental students, but there is no study regarding the perception of dental students among the grades about altered level of gingival smile with crown lengthening. ${ }^{[8-11]}$

The aim of the current study was to evaluate the perception of smile esthetics and alterations in dentistry degree students determining whether there are educational differences among classes (from $1^{\text {st }}$ to $5^{\text {th }}$ ) about gingival plastic surgery, by means of alterations in smile photograph.

\section{MATERIALS AND METHODS}

To perform current study, 40 years old woman's frontal smile photograph with normal occlusion, was used with the courtesy of Pithon et al. ${ }^{[10]}$ This photograph was obtained with a digital photograph machine (Canon Rebel XTI, 10 megapixels) and cropped as an image including the lips, gingiva and teeth. The images used by Pithon were created that the various lengths of gingiva were removed from the maxillary teeth to simulate the feasible outcome of gingival plastic surgery with crown lengthening. The eight photographs were composed of removing $0.5,1,1.5,2,2.5,3$ and $3.5 \mathrm{~mm}$ of maxillary gingival height and the original one [Figure 1]. No changes were done on these images by us.

The photographs were evaluated by 216 dentistry students of whom $47.7 \%$ male $(n=103)$ and $52.3 \%$ female $(n=113)$ in five class groups $\left(1^{\text {st }}, 2^{\text {nd }}, 3^{\text {rd }}, 4^{\text {th }}\right.$ and $5^{\text {th }}$ classes) studying at Kirikkale University, Faculty of Dentistry, Kirikkale [Table 1]. None of the students had received orthodontic treatment. The images were prepared as a questionnaire and asked to students. On the first sheet, the series of miniature images $(4.6 \mathrm{~cm} \times 4.8 \mathrm{~cm}-1-8)$ was printed and chosen by students as the most and the least pleasing images [Figure 1a]. The process was repeated on a second sheet with the altered distribution of the same images of Figure 1a to evaluate the reliability of the students' answers [Figure 1b]. Finally, students evaluated the larger size of each photograph $(20 \mathrm{~cm} \times 19 \mathrm{~cm})$ of Figure 1a randomly and individually using a scale of attractiveness: 10 , the most attractive; 5 , attractive and 0 , the least attractive. The students were not allowed to make comparisons among images. The image evaluation time for each image was limited to $10 \mathrm{~s}$ and placed at a distance of $30 \mathrm{~cm}$ from the students' eyes.

The Chi-square test was performed to determine the frequencies of replies by the students in each dental class group. When the expected frequency was $<5$, the Fisher exact test was used. To compare the given values to each photograph, the Kruskal-Wallis test was used and to compare pairs the Mann-Whitney test also. The level of significance adopted was 5\% $(P<0.05)$. The data sets were analyzed with statistical software (IBM SPSS Version 20, IBM Germany).

\section{RESULTS}

Tables 2 and 3 show the perceptions of students with respect to the differences and preferences regarding Figure $1 \mathrm{a}$ and $\mathrm{b}$, respectively. The results revealed that almost all of the class' students perceived differences between images additionally the highest percentage of students that answered "no difference" was $12 \%$ at $1^{\text {st }}$ class' students. There was no significant difference in the frequency of replies among the classes for both images $(P=0.32$ and $P=0.31$, respectively).

Tables 2 and 3 show the perceptions of students with respect to the differences and preferences regarding Figure $1 \mathrm{a}$ and $\mathrm{b}$, respectively.

Table 2 shows that $1^{\text {st }}$ and $2^{\text {nd }}$ class students liked Photograph 4 the most and $3^{\text {rd }}$ class students liked Photograph 4 and 5 the most with the percentage of $31.8 \%, 31.1 \%$, and $26.2 \%$ whereas $4^{\text {th }}$ class students preferred Photograph 6 and 7, $5^{\text {th }}$ class students preferred Photograph 6 as the most with the percentage 


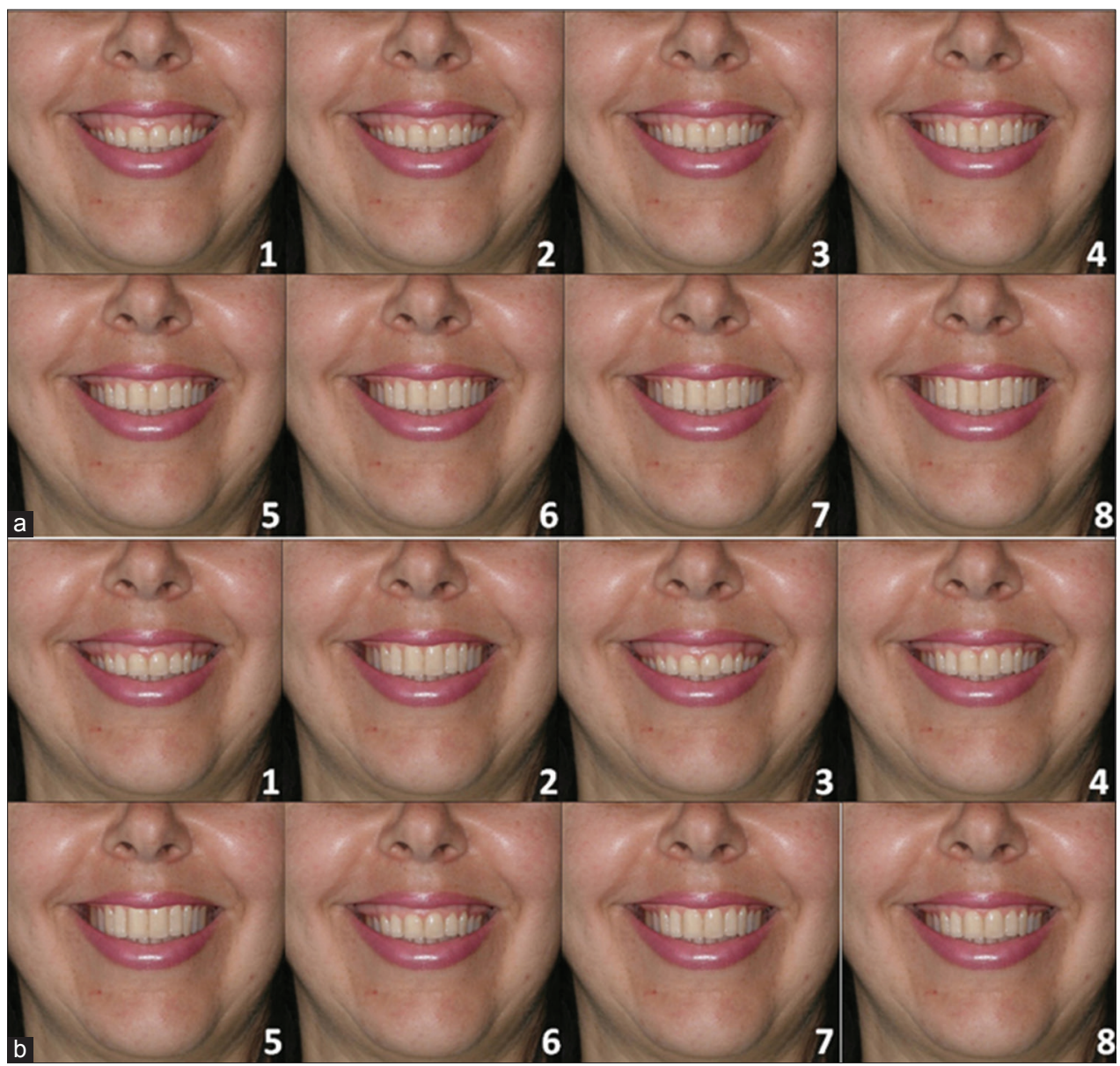

Figure 1: (a) (1) Smile without any alteration, with 4.0, (2) 3.5, (3) 3.0, (4) 2.5, (5) 2.0, (6) 1.5, (7) 1.0, (8) and 0.5 mm of gum exposure. (b) (1) Smile with $3.5 \mathrm{~mm}$ of gum exposure (2) $1.0 \mathrm{~mm}$, (3) Smile without any alteration, and smile with 4.0, (4) 2.5, (5) 0.5, (6) 3.0, (7) 1.5 , and (8) $2.0 \mathrm{~mm}$ of gum exposure

\begin{tabular}{|c|c|c|c|c|c|c|}
\hline \multirow[t]{3}{*}{ Sex } & \multicolumn{5}{|c|}{ Class $n=216$} & \multirow{3}{*}{$\begin{array}{c}\text { Sum } \\
n=216\end{array}$} \\
\hline & 1 & 2 & 3 & 4 & 5 & \\
\hline & $n=50$ & $n=46$ & $n=44$ & $n=38$ & $n=38$ & \\
\hline Male & $25(50.0 \%)$ & $22(47.8 \%)$ & $18(40.9 \%)$ & $20(52.6 \%)$ & $18(47.4 \%)$ & $103(47.7 \%)$ \\
\hline Female & $25(50.0 \%)$ & $24(52.2 \%)$ & $26(59.1 \%)$ & $18(47.4 \%)$ & 20 (52.6\%) & $113(52.3 \%)$ \\
\hline
\end{tabular}

of $24.3 \%$ and $38.9 \%$, respectively. Photograph 8 was selected by the $1^{\text {st }}$ and $2^{\text {nd }}$ class $(52.3 \%$ and $60.0 \%)$ whereas Photograph 1 was selected by the other classes as the least preferred ones $(71.4 \%, 75.7 \%$ and $69.4 \%)$.

For Figure $1 b$, Table 3 reveals that $1^{\text {st }}$ and $3^{\text {rd }}$ class students preferred Photograph 4 (29.5\% and $30.2 \%), 2^{\text {nd }}$ class student Photograph $6(28.5 \%)$ and $4^{\text {th }}$ and $5^{\text {th }}$ class students preferred Photograph $7(29.7 \%$ and $36.1 \%)$ as the most liked. Photograph 5 was selected by the $1^{\text {st }}$ and $2^{\text {nd }}$ class students (36.4\% and 47.7$)$, Photograph 3 was selected by the $3^{\text {rd }}$ class students $(34.9 \%)$ and Photograph 1 was selected by the $4^{\text {th }}$ and $5^{\text {th }}$ class students (45.9\% and $41.7 \%)$ as the least preferred ones.
The mean scores awarded to each photograph are presented in Table 4. In this Table 4, Photograph 5 was scored by the $1^{\text {st }}$ and $2^{\text {nd }}$ classes, Photograph 4 was scored by the $3^{\text {rd }}$ class, Photograph 6 was scored by the $4^{\text {th }}$ and $5^{\text {th }}$ classes as the most attractive while Photograph 8 was scored by $1^{\text {st }}$ and $2^{\text {nd }}$ classes and Photograph 1 was scored by $3^{\text {rd }}, 4^{\text {th }}$, and $5^{\text {th }}$ classes as the least attractive. The scores awarded to Photograph 1, 6, 7, and 8 presented significant differences among the classes. Comparisons between class groups showed that $2^{\text {nd }}, 4^{\text {th }}$, and $5^{\text {th }}$ class students attributed better scores to these four photographs when compared with other class students. 
Ayyildiz, et al.: Gingival plastic surgery from the students' perspective

\begin{tabular}{|c|c|c|c|c|c|c|}
\hline \multirow[t]{2}{*}{ Answer } & \multicolumn{5}{|c|}{ Class } & \multirow[t]{2}{*}{$P$ value } \\
\hline & 1 & 2 & 3 & 4 & 5 & \\
\hline \multicolumn{7}{|c|}{ Perceive Differences } \\
\hline Yes & $44(88.0 \%)$ & $45(97.8 \%)$ & $42(95.5 \%)$ & $37(97.4 \%)$ & $36(94.7 \%)$ & 0.32 \\
\hline No & $6(12.0 \%)$ & $1(2.2 \%)$ & $2(4.5 \%)$ & $1(2.6 \%)$ & $2(5.3 \%)$ & \\
\hline \multicolumn{7}{|c|}{ Image 1 like most } \\
\hline 1 & $3(6.8 \%)$ & $3(6.7 \%)$ & 0 & 0 & 0 & $<0.0011^{\dagger}$ \\
\hline 2 & $7(15.9 \%)$ & $6(13.3 \%)$ & $2(4.8 \%)$ & 0 & 0 & \\
\hline 3 & $4(9.1 \%)$ & $10(22.2 \%)$ & $4(9.5 \%)$ & $1(2.7 \%)$ & $1(2.8 \%)$ & \\
\hline 4 & $14(31.8 \%)$ & $14(31.1 \%)$ & $11(26.2 \%)$ & $7(18.9 \%)$ & $5(13.9 \%)$ & \\
\hline 5 & $7(15.9 \%)$ & $6(13.3 \%)$ & $11(26.2 \%)$ & $8(21.6 \%)$ & $8(22.2 \%)$ & \\
\hline 6 & $1(2.3 \%)$ & $2(4.4 \%)$ & $5(11.9 \%)$ & $9(24.3 \%)$ & $14(38.9 \%)$ & \\
\hline 7 & $6(13.6 \%)$ & 0 & $7(16.7 \%)$ & $9(24.3 \%)$ & $4(11.1 \%)$ & \\
\hline 8 & $2(4.5 \%)$ & $4(8.9 \%)$ & $2(4.8 \%)$ & $3(8.1 \%)$ & $4(11.1 \%)$ & \\
\hline \multicolumn{7}{|c|}{ Image 1 like least } \\
\hline 1 & $13(29.5 \%)$ & $12(26.7 \%)$ & $30(71.4 \%)$ & $28(75.7 \%)$ & $25(69.4 \%)$ & $<0.001 \dagger$ \\
\hline 2 & $4(9.1 \%)$ & $1(2.2 \%)$ & 0 & $1(2.7 \%)$ & $1(2.8 \%)$ & \\
\hline 3 & $2(4.5 \%)$ & 0 & 0 & 0 & 0 & \\
\hline 4 & $1(2.3 \%)$ & 0 & 0 & 0 & 0 & \\
\hline 5 & 0 & $1(2.2 \%)$ & $1(2.4 \%)$ & 0 & 0 & \\
\hline 6 & 0 & 0 & 0 & 0 & 0 & \\
\hline 7 & $1(2.3 \%)$ & $4(8.9 \%)$ & 0 & 0 & $3(8.3 \%)$ & \\
\hline 8 & $23(52.3 \%)$ & $27(60.0 \%)$ & $11(26.2 \%)$ & $8(21.6 \%)$ & $7(19.5 \%)$ & \\
\hline
\end{tabular}

${ }^{*}$ Answered only by those who perceived differences between the images; ${ }^{~}$ Chi-square test; ${ }^{\dagger}$ Fisher exact test

\begin{tabular}{|c|c|c|c|c|c|c|}
\hline \multirow[t]{2}{*}{ Answer } & \multicolumn{5}{|c|}{ Class } & \multirow[t]{2}{*}{$P$ Value } \\
\hline & 1 & 2 & 3 & 4 & 5 & \\
\hline \multicolumn{7}{|c|}{ Perceive Differences } \\
\hline Yes & $44(88.0 \%)$ & $42(91.3 \%)$ & $43(97.7 \%)$ & $37(97.4 \%)$ & $36(94.7 \%)$ & $0.316^{*}$ \\
\hline No & $6(12.0 \%)$ & $4(8.7 \%)$ & $1(2.3 \%)$ & $1(2.6 \%)$ & $2(5.3 \%)$ & \\
\hline \multicolumn{7}{|c|}{ Image 2 like most } \\
\hline 1 & $6(13.6 \%)$ & $5(11.9 \%)$ & $1(2.3 \%)$ & 0 & 0 & $<0.001^{\dagger}$ \\
\hline 2 & $3(6.8 \%)$ & 0 & $8(18.6 \%)$ & 0 & $3(8.3 \%)$ & \\
\hline 3 & $4(9.1 \%)$ & 0 & $3(7.0 \%)$ & $1(2.7 \%)$ & 0 & \\
\hline 4 & $13(29.5 \%)$ & $9(21.4 \%)$ & $13(30.2 \%)$ & $8(21.6 \%)$ & $9(25.0 \%)$ & \\
\hline 5 & $2(4.5 \%)$ & $4(9.6 \%)$ & 0 & $8(21.6 \%)$ & $5(13.9 \%)$ & \\
\hline 6 & $7(15.9 \%)$ & $12(28.5 \%)$ & $2(4.7 \%)$ & $1(2.7 \%)$ & $2(5.6 \%)$ & \\
\hline 7 & $3(6.8 \%)$ & $2(4.8 \%)$ & $6(14.0 \%)$ & $11(29.7 \%)$ & $13(36.1 \%)$ & \\
\hline 8 & $6(13.6 \%)$ & $10(23.8 \%)$ & $10(23.3 \%)$ & $8(21.6 \%)$ & $4(11.1 \%)$ & \\
\hline \multicolumn{7}{|c|}{ Image 2 like least } \\
\hline 1 & $7(15.9 \%)$ & $5(12.0 \%)$ & $10(23.3 \%)$ & $17(45.9 \%)$ & $15(41.7 \%)$ & $0.007^{\dagger}$ \\
\hline 2 & $7(15.9 \%)$ & $6(14.2 \%)$ & $3(7.0 \%)$ & $4(10.8 \%)$ & $1(2.8 \%)$ & \\
\hline 3 & $9(20.5 \%)$ & $7(16.7 \%)$ & $15(34.9 \%)$ & $8(21.6 \%)$ & $13(36.1 \%)$ & \\
\hline 4 & $1(2.3 \%)$ & 0 & 0 & 0 & $1(2.8 \%)$ & \\
\hline 5 & $16(36.4 \%)$ & $20(47.7 \%)$ & 12 (27.9\%) & $5(13.5 \%)$ & $5(13.9 \%)$ & \\
\hline 6 & $1(2.3 \%)$ & 0 & $1(2.3 \%)$ & $2(5.4 \%)$ & 0 & \\
\hline 7 & 0 & $2(4.7 \%)$ & $1(2.3 \%)$ & $1(2.7 \%)$ & $1(2.8 \%)$ & \\
\hline 8 & $3(6.8 \%)$ & $2(4.7 \%)$ & $1(2.3 \%)$ & 0 & 0 & \\
\hline
\end{tabular}

${ }^{*}$ Answered only by those who perceived differences between the images; ${ }^{\dagger}$ Chi-square test; ${ }^{\dagger}$ Fisher exact test

\section{DISCUSSION}

The smile attractiveness is the most important component of the facial esthetics. When designing the true smile, these should be considered effectively; gingival exposure, smile line, height and harmony of the marginal gingiva, size and proportion of the maxillary teeth. ${ }^{[12]}$ 
Ayyildiz, et al.: Gingival plastic surgery from the students' perspective

\begin{tabular}{|c|c|c|c|c|c|c|}
\hline \multirow[t]{2}{*}{ Photograph } & \multicolumn{5}{|c|}{ Class } & \multirow[t]{2}{*}{$P$ value } \\
\hline & 1 & 2 & 3 & 4 & 5 & \\
\hline Image 1 & $2.64(1.89)^{a}$ & $3.28(2.21)^{a}$ & $2.41(1.46)^{a}$ & $2.34(2.32)^{b}$ & $1.95(1.69)^{b}$ & 0.023 \\
\hline Image 2 & $3.50(2.07)$ & $3.41(2.38)$ & $3.16(1.87)$ & 3.03 (1.95) & 3.00 (1.69) & NS \\
\hline Image 3 & $4.80(2.38)$ & $4.54(2.20)$ & $4.39(1.60)$ & $3.92(2.05)$ & $3.66(1.89)$ & NS \\
\hline Image 4 & $4.80(2.12)$ & $4.04(1.88)$ & $5.20(1.77)$ & $4.66(1.90)$ & $4.63(1.44)$ & NS \\
\hline Image 5 & 4.88 (1.93) & $4.67(2.23)$ & $5.09(1.44)$ & $4.79(1.84)$ & $4.92(1.76)$ & NS \\
\hline Image 6 & $3.26(2.17)^{a}$ & $2.87(2.21)^{a}$ & $4.41(2.29)^{b}$ & $4.82(2.57)^{\mathrm{b}}$ & $5.42(2.37)^{\mathrm{b}}$ & $<0.001$ \\
\hline Image 7 & $3.16(2.16)^{\mathrm{a}}$ & $2.30(2.40)^{b}$ & $3.75(2.30)^{a}$ & $4.63(2.62)^{c}$ & $5.08(2.21)^{c}$ & $<0.001$ \\
\hline Image 8 & $1.74(1.99)^{a}$ & $1.78(2.59)^{a}$ & $3.50(2.80)^{\mathrm{b}}$ & $4.05(2.42)^{b}$ & $3.97(3.08)^{b}$ & $<0.001$ \\
\hline
\end{tabular}

The scores were compared with Kruskal-Wallis test. Values with different superscript letters are significantly different (Mann-Whitney test).

One to $3 \mathrm{~mm}$ gingival display is defined as normal esthetically. ${ }^{[4]}$ Excessive gingival display meaning gummy smile $(>3 \mathrm{~mm})$ is usually accepted unesthetic. ${ }^{[6,13,14]}$ Vertical skeletal maxillary excess which is one of the most crucial etiology of gummy smileis reduced with a Le Fort I impaction but if there is a contraindication of orthognathic surgery or unwillingness of the patient for surgery, this type of treatment is impractical. In this case, effective treatment of gummy smile can be performed with crown lengthening via gingival plastic surgery. While performing this procedure, the harmony between the clinical crown size and gingival display when smiling is a critical role in esthetics and has clinical relevance in orthodontics, periodontics and prosthodontics.

When planning the orthodontic treatment, it is important to know the patient's opinion about esthetics as well as to know the esthetic perception of orthodontists whom make the treatment. The esthetic perception of dentists is strongly correlated with educational backgrounds. In the first 2 years of dental education, basic medical sciences are predominated and professional courses are included limitedly in education curriculum. Whereas after the $2^{\text {nd }}$ class, professional lessons are predominated and clinical practices are started. Especially, the photography lesson is learned in this class and the orthodontic internship and case discussions are started also by the lecturer of department of orthodontics and these can be contributed to development of students' esthetic perception. The studies analyzing the perception of smile esthetics in the literature were generally about dental professionals, laypersons, or dental students. ${ }^{[8-10]}$ However, there is only one study comparing the perception of smile esthetics and alterations in dentistry degree students. ${ }^{[15]}$ Therefore, the results of the current study presented original outcomes.

There are lots of studies in the literature using modified smile photographs as current study which is evaluated by different age groups, occupational and social groups also. ${ }^{[10,16-19]}$ Our findings indicated that there were statistical significant differences among different study years for both Figure 1a and b. In Figure 1a, the $1^{\text {st }}$ and $2^{\text {nd }}$ class students most liked Photograph 4 and $3^{\text {rd }}$ class students liked Photograph 4 and 5 whereas $4^{\text {th }}$ class students preferred Photograph 6 and $7,5^{\text {th }}$ class students preferred Photograph 6 as the most. As for the least ones; $1^{\text {st }}$ and $2^{\text {nd }}$ class disliked Photograph 8 but the other classes disliked Photograph 1 (original) [Table 2]. The results demonstrated that esthetic perception of smile improve as a student passes to higher study classes in terms of gingival exposure. Our results were incompatible with that of España et al. ${ }^{[15]}$ They suggested that there were statistically significant differences among different study years, but this condition didn't show a linear improvement from $1^{\text {st }}$ to $5^{\text {th }}$ dental degree classes.

As for Figure $1 \mathrm{~b}$, the $1^{\text {st }}$ and $3^{\text {rd }}$ class students most liked Photograph 4 and $2^{\text {nd }}$ class students liked Photograph 6 whereas $4^{\text {th }}$ and $5^{\text {th }}$ class students preferred Photograph 7. As for the least ones; $1^{\text {st }}$ and $2^{\text {nd }}$ class disliked Photograph 5, $3^{\text {rd }}$ class disliked Photograph 3 (original) but the other classes disliked Photograph 1 [Table 3]. For Figure 1a and b, our findings were similar with the results of Pithon et al. ${ }^{[10]}$ and contrast to that of Malkinson et al. ${ }^{[17]}$ Additionally, the preferences of $3^{\text {rd }}, 4^{\text {th }}$ and $5^{\text {th }}$ classes were also similar with some other study results. ${ }^{[10,20-22]}$

Ioi et al. ${ }^{[11]}$ demonstrated that the dental students selected the smile with $2 \mathrm{~mm}$ of lip coverage of the upper central incisors as the most attractive. Whereas in our study, $1^{\text {st }}$ and $2^{\text {nd }}$ class students disliked images which visible only crowns of teeth when smiling.

\section{CONCLUSION}

- There were significant differences among dental degree classes when judging the gingival smile on facial esthetics 
- This perceptional difference might be resulted from different educational program at each class such as photography lesson, orthodontic internship, case discussions and the preclinical period including prosthetic courses

- The harmonious display of gingiva exhibits an important effect in the smile esthetics rather than reduced or excessive display. Up to $3 \mathrm{~mm}$ gingival display is defined as acceptable so it should be considered in the evaluation of smile esthetics by orthodontists, periodontologists and prosthodontists.

\section{Financial support and sponsorship}

Nil.

\section{Conflicts of interest}

There are no conflicts of interest.

\section{REFERENCES}

1. Marchiori GE, Sodré LO, da Cunha TC, Torres FC, Rosário HD, Paranhos LR. Pleasantness of facial profile and its correlation with soft tissue cephalometric parameters: Perception of orthodontists and lay people. Eur J Dent 2015;9:352-5.

2. Flanary C. The psychology of appearance and psychological impact of surgical alteration of the face. In: Bell WH, editor. Modern Practice in Orthognathic and Reconstructive Surgery. Philadelphia, PA: Saunders; 1992.

3. Abraham A, George J, Peter E, Philip K, Chankramath R, Johns DA, et al. Establishment of a new relationship between posed smile width and lower facial height: A cross-sectional study. Eur J Dent 2015;9:394-9.

4. An KY, Lee JY, Kim SJ, Choi JI. Perception of maxillary anterior esthetics by dental professionals and laypeople and survey of gingival topography in healthy young subjects. Int J Periodontics Restorative Dent 2009;29:535-41.

5. Ahmad I. Geometric considerations in anterior dental aesthetics: Restorative principles. Pract Periodontics Aesthet Dent 1998;10:813-22.

6. Garber DA, Salama MA. The aesthetic smile: Diagnosis and treatment. Periodontol 2000 1996;11:18-28.
7. Claman L, Alfaro MA, Mercado A. An interdisciplinary approach for improved esthetic results in the anterior maxilla. J Prosthet Dent 2003;89:1-5.

8. Heravi F, Rashed R, Abachizadeh H. Esthetic preferences for the shape of anterior teeth in a posed smile. Am J Orthod Dentofacial Orthop 2011;139:806-14.

9. McLeod C, Fields HW, Hechter F, Wiltshire W, Rody W Jr., Christensen J. Esthetics and smile characteristics evaluated by laypersons. Angle Orthod 2011;81:198-205.

10. Pithon MM, Santos AM, Campos MS, Couto FS, dos Santos AF, Coqueiro Rda S, et al. Perception of laypersons and dental professionals and students as regards the aesthetic impact of gingival plastic surgery. Eur J Orthod 2014;36:173-8.

11. Ioi H, Nakata S, Counts AL. Influence of gingival display on smile aesthetics in Japanese. Eur J Orthod 2010;32:633-7.

12. Morley J, Eubank J. Macroesthetic elements of smile design. J Am Dent Assoc 2001;132:39-45.

13. Monaco A, Streni O, Marci MC, Marzo G, Gatto R, Giannoni M. Gummy smile: Clinical parameters useful for diagnosis and therapeutical approach. J Clin Pediatr Dent 2004;29:19-25.

14. Dong JK, Jin TH, Cho HW, Oh SC. The esthetics of the smile: A review of some recent studies. Int J Prosthodont 1999;12:9-19.

15. España P, Tarazona B, Paredes V. Smile esthetics from odontology students' perspectives. Angle Orthod 2014;84:214-24.

16. Parekh S, Fields HW, Beck FM, Rosenstiel SF. The acceptability of variations in smile arc and buccal corridor space. Orthod Craniofac Res 2007;10:15-21.

17. Wolfart S, Brunzel S, Freitag S, Kern M. Assessment of dental appearance following changes in incisor angulation. Int J Prosthodont 2004;17:150-4.

18. Correa BD, Vieira Bittencourt MA, Machado AW. Influence of maxillary canine gingival margin asymmetries on the perception of smile esthetics among orthodontists and laypersons. Am J Orthod Dentofacial Orthop 2014;145:55-63.

19. Cotrim ER, Vasconcelos Júnior ÁV, Haddad AC, Reis SA. Perception of adults' smile esthetics among orthodontists, clinicians and laypeople. Dental Press J Orthod 2015;20:40-4.

20. Van der Geld P, Oosterveld P, Schols J, Kuijpers-Jagtman AM. Smile line assessment comparing quantitative measurement and visual estimation. Am J Orthod Dentofacial Orthop 2011;139:174-80.

21. Zawawi KH, Malki GA, Al-Zahrani MS, Alkhiary YM. Effect of lip position and gingival display on smile and esthetics as perceived by college students with different educational backgrounds. Clin Cosmet Investig Dent 2013;5:77-80.

22. Malkinson S, Waldrop TC, Gunsolley JC, Lanning SK, Sabatini R. The effect of esthetic crown lengthening on perceptions of a patient's attractiveness, friendliness, trustworthiness, intelligence, and self-confidence. J Periodontol 2013;84:1126-33. 